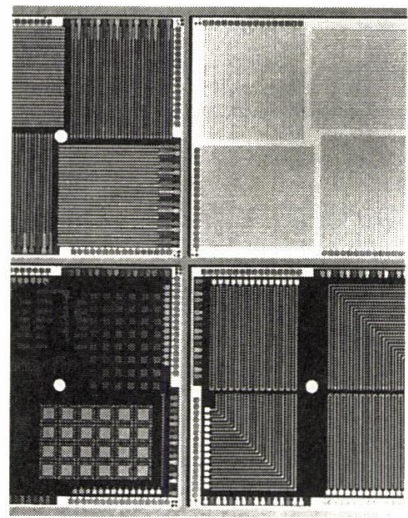

\title{
ハイビジョンテレビの実装対策 とノイズ対策
}

Mount Technology \& Noise Reduction on HDTV

\begin{tabular}{|c|c|}
\hline 英幸*1 & 小松 \\
\hline 䂑場 正男*3 & 森田 \\
\hline
\end{tabular}

\section{1.はじめに}

ソニーは, 32 型のフルスペック・ハイビジョンテレビ $\ulcorner\mathrm{KW}-3200 \mathrm{HD}$ 」を 1992 年 7 月に発売した。このテレ ビは第 2 世代の MUSE デコーダを搭載し, 従来の約 5 倍の情報をもつハイビジョンの素晴らしい画を映し出す ことができる。バルセロナ・オリンピックの名場面を八 イビジョン放送で楽しまれた方も扔られると思う。

KW-3200 HD は, MUSEデコーダを初め, さまざま な楽しい機能を内蔵しており, 回路基板は小型化と高信

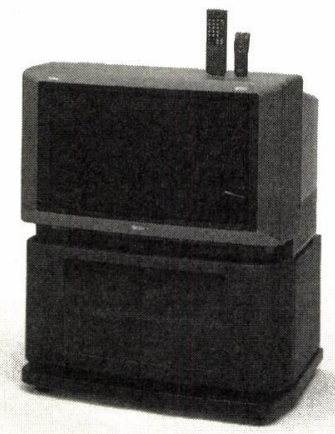

Fig.1 Full specification HDTV set (KW-3200HD).

* 1 Hideyuki Yamada\ソニー侏映像機器開発本部 /SONY Corp., Display Development Group.

* 2 Nobuo Komatsu】同電子デバイス事業本部/SONY Corp., Electronic Devices Group.

* 3 Masao Kayaba, Kouji Morita $\triangleright$ 同映像関連技術部門 / SONY Corp., Display Engineering Productization.
頼化の実現のため，高密度実装技術やいろいろの工夫を 図った。従来のテレビに比べ, デジタル回路や広帯域ビ デオ回路など各種回路から出るさまざまな信号周波数間 の干渉による画面障害と, 機外への不要輻射妨害を防止 するノイズ対策が重要になる。

本稿では，KW-3200 HDの基板実装技術，MUSEデ コーダのノイズ対策，EMI シールド基板の特性につい て紹介する。

\section{MUSE 基板とクロック}

今日のテレビには，デジタル回路が多く使われている。 デジタル回路を使用した機器には, 常に高調波ノイズの 問題が付きまとう。特に商品化には, このノイズ対策技 術が非常に重要である。八イビジョンテレビの心臟部で ある，MUSEデコーダのノイズ対策技術を紹介する。
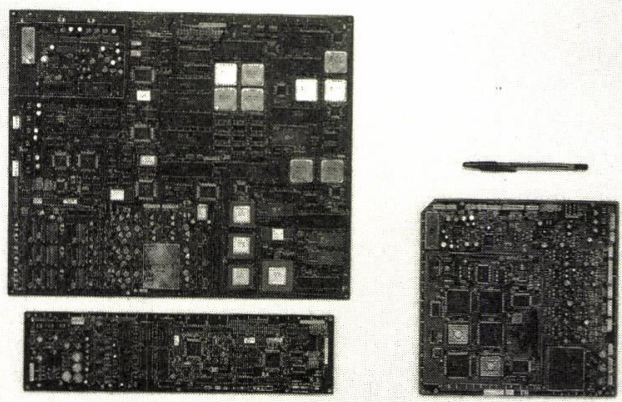

1'st Version 2'nd Version

Fig.2 MUSE decoder PCB. $S H M$ 会誌 


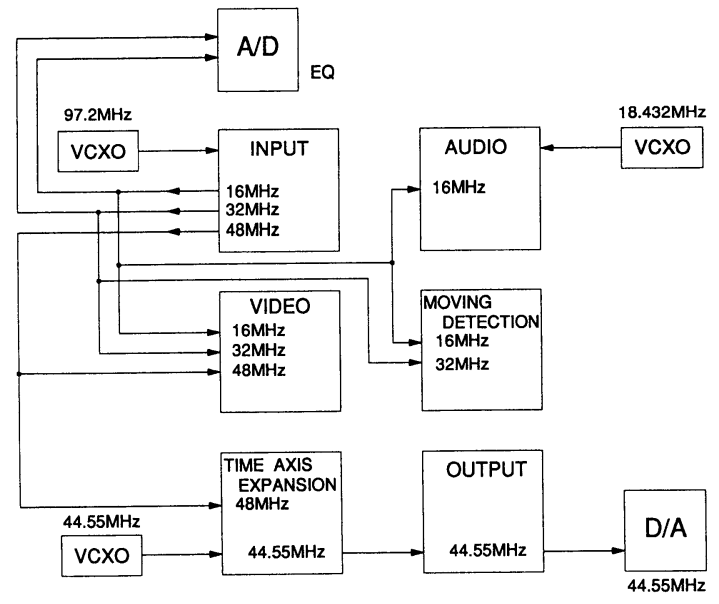

Fig.3 Clock flow.

Tab.1(a) Clock frequency in the MUSE decorder. ( $\mathrm{MHz}$ )

\begin{tabular}{c|c|c|c}
\hline & VCXO & Devided frequency & Purpose \\
\hline F1 & 97.2 & $\ldots .$. & Video system clock \\
\hline F2 & $\prime \prime$ & 48.6 & Video system clock \\
\hline F3 & $\prime \prime$ & 32.4 & Video system clock \\
\hline F4 & $\prime \prime$ & 16.2 & Video system clock \\
\hline F5 & 44.55 & $\ldots . .$. & Video time axis expansion \\
\hline F6 & 18.432 & $\ldots .$. & Sound system clock \\
\hline
\end{tabular}

Tab.1(b) Internal jamming frequency. ( $\mathrm{MHz})$

\begin{tabular}{c|c|c|c|c}
\hline \multicolumn{2}{c|}{ Broadcast } & \multicolumn{2}{c|}{ Jamming } & \multirow{2}{*}{$\begin{array}{c}\text { Beat } \\
\text { frequency }\end{array}$} \\
\cline { 1 - 4 } CH & Frequency & Frequency & Higher harmonics & 0.05 \\
\hline 2 & 97.25 & 97.2 & $97.2 \times 1$ & 0.95 \\
\hline 5 & 177.25 & 178.2 & $44.55 \times 4,16.2 \times 11$ & 0.15 \\
\hline 8 & 193.25 & 194.4 & $48.6 \times 4,32.4 \times 6$ & 1.15 \\
\hline
\end{tabular}

Fig.1に KW-3200 HD, Fig.2に MUSE デコーダ基板 を示す。MUSE デコーダは，衛星から送られてきた MUSE 方式の信号を，ハイビジョン信号にデコードす るものである。

今回は第 2 世代 MUSE·LSI（日立，富士通，TI，ソ ニーの 4 社で共同開発）を使用することにより，第 1 世 代で 150 個使用していた IC を 30 個にまで削減するこ とができ，大幅な小型化，低消費電力化，コストダウン を実現することができた。基板面積，消費電力とも，第 1 世代と比較すると 3 分の 1 程度である。

MUSEデコーダは，その信号処理に多数のクロック 周波数を使用しているため, 設計当初からノイズ対策を

Vol.9, No.3
考えておき，事前に盛り込んでおく必要がある。この場 合のノイズによる妨害には，2つのレベルがある。ひと つはいわゆる不要輻射としての機外妨害，もうひとつは 機器内の映像系と音声系にノイズを与える機内妨害であ る。どちらの妨害に対しても，発生源を完全に抑えるこ とが重要である。

Fig.3に, MUSE デコーダのクロックとその流れにつ いて図示する。97.2 MHz（VCXO）から分周された $16.2 \mathrm{MHz}, 32.4 \mathrm{MHz}$ および $48.6 \mathrm{MHz}$ と, 時間軸伸 長の $44.55 \mathrm{MHz}$ (VCXO) が主に映像処理で使用され, $18.432 \mathrm{MHz}$ は音声処理で使用される。全部で 6 種類の クロックが常に動作しており，信号レベルは， $5 \mathrm{~V}$ CMOS レベルである。

Tab.1 (a)にクロックリストを示す。MUSE デコーダ のクロック高調波のうち, いくつかはチュー十部に飛び 込み， $2 \mathrm{CH} ， 5 \mathrm{CH} ， 8 \mathrm{CH}$ に縞模様のクロスビートを 引き起こす原因になる。Tab.1(b)に，この関係のクロッ ク高調波, 放送周波数, ビート周波数を示す。

\section{3.ノイズ対策設計}

MUSE デコーダ基板で実施した対策を列記する。

(1) 4 層基板の使用

(2)アナログ/デジタル GNDの分離と接続

(3)スルーホール接続

(4)入出力対策

(5) EMSCAN $の$ 利用

\section{(1) 4 層基板}

内層に電源・GNDを，外層に信号パターンを配線し た。外層で空いた部分はべ夕 GND とし，内層 GNDと 多点で接続（TH）することにより $5 \sim 6 \mathrm{~dB}$ の効果がみ られた。 4 層基板の構成は別に詳述する。

\section{(2)アナログ/デジタル GND の分離と接続}

基板内の GND はデジタル部とアナログ部とで分離を しているが，それぞれの GND 間で電位差を生ずる所が 出るため, 数箇所で直接接続を行っている。これは EMSCAN で測定しながら, 最も効果のあるポイントを 捜した。10 dB 以上の効果を得ることができた。

\section{(3)スルーホール接続}

この基板で使用している LSI は，すべて表面実装夕 イプであるので, GND ピンはパターンでGND と接続 させる必要がある。しかし, 単に GND と接続している のではなく, 近くのべタ GND と接続し, 多数の TH により内層 GND とも接続している。この GND 強化は ノイズ低減効果もあるが，熱を基板内に拡散する効果も 見逃してはならない。Fig.4 (a)に LSI 周囲の GNDに配 


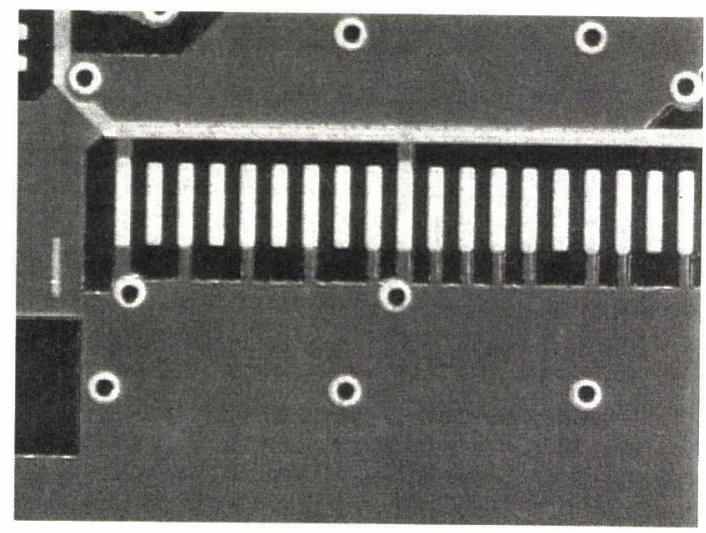

Fig. 4(a) No connection pins are jointing vast GND pattern.

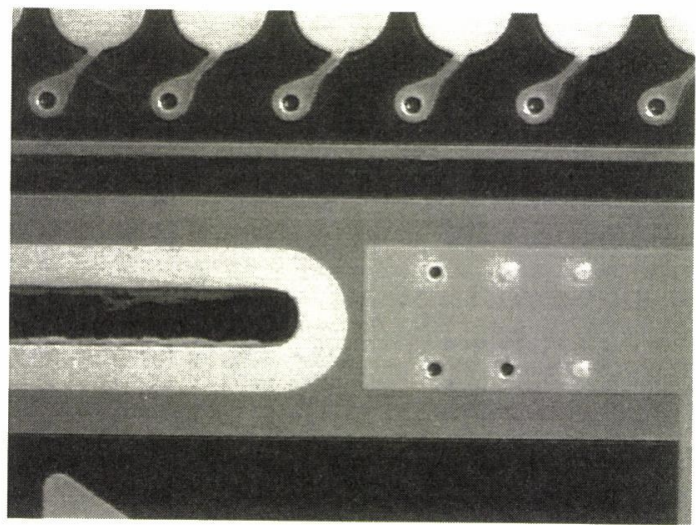

Fig.4(b) Many VIA holes located around shield case terminal.

\section{した THを示す。}

シールドケース足の周囲も, 内層 GNDに多数の TH を増やしてGNDのインピーダンスを低く抑えることが できた。同図(b)にこれを示す。

\section{(4)入出力端子対策}

MUSE デコーダと接続する電源, 各種信号の端子に は，信号の種類により EMI フィルタを使い分けて対策 を行った。それらをTab.2に示す。

Tab.2 I/O Terminal EMI filter.

\begin{tabular}{c|c|c}
\hline Terminal & EMI Filter & Effect \\
\hline Audio & Solid inducter & Low pass filter \\
Video & LC Type filter & Low pass filter \\
Clock & $47 \mathrm{pF}$ & Low pass filter \\
Mode & $1000 \mathrm{pF}$ & Low pass filter \\
Power & $0.1 \mu \mathrm{F}$ & Low pass filter \\
\hline
\end{tabular}

Prototype PWB

EMSCAN (Spectral)

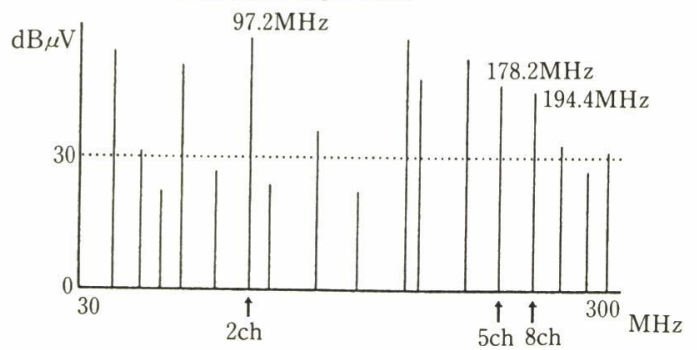

$\operatorname{EMSCAN}($ Spatial)

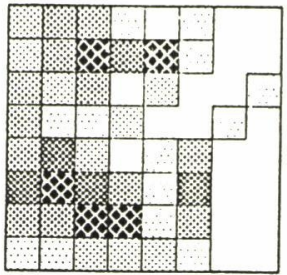

$f=178.2 \mathrm{MHz}$

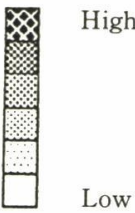

Final PWB

EMSCAN (Spectral)

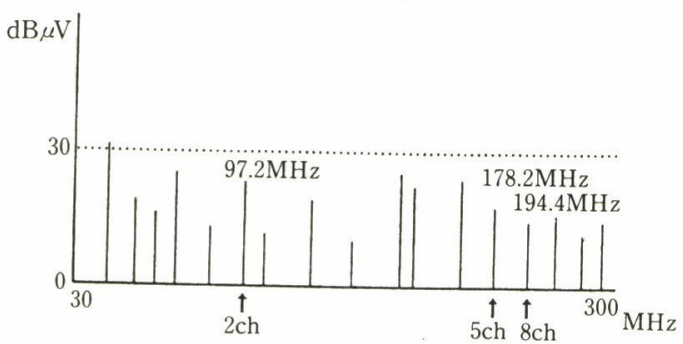

EMSCAN (Spatial)

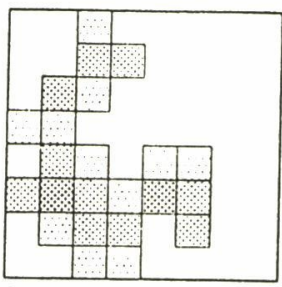

$\mathrm{f}=178.2 \mathrm{MHz}$

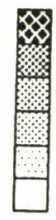

High

Fig.5 EMSCAN (Spectral \& noise levelmap). 


\section{(5) EMSCAN}

今回のノイズ対策に使用した測定システムである。 1,280 個 $(32 \times 40)$ のループ・アンテナを使い, 周波数 の強度分布と, 特定周波数の平面強度分布を測定するこ とができる。これらを使い，デジタルとアナログの GND 接続ポイントを捜したり, 放送周波数帯に直接影 響を与える周波数（クロック高調波）に対して強力な対 策を施すことをしたり，非常に効果的な対策を選ぶこと ができ, 素早く基板設計にフィードバックすることもで きた。ノイズ対策の検討に要した時間は約 1.5 日だけで 済んだ。実際のノイズ電界の分布は, 強度に対応した色 別表示だが，ここには模式的に表したノイズ平面強度分 布とノイズ周波数分布を Fig.5 に示す。対策前のスペク トラムと基板内の平面強度の分布が，対策後は見事に低 下したことがわかる。

\section{EMI シールド基板のノイズ削減特性}

今回ノイズ対策と並行して，当社の EMI シールド基 板で検討したこの特性を紹介する。

\section{(1)基板構造}

この基板の断面構造を Fig.6 に示す。通常の基板の上 にGNDに接地されたシールド板が貼り合わされていて，

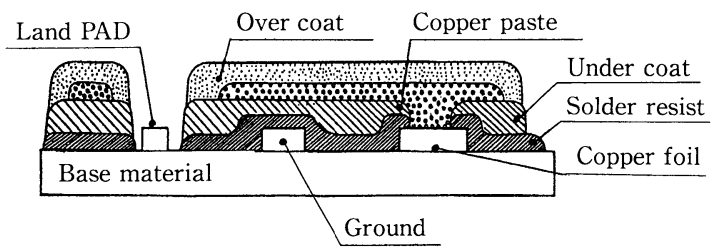

Fig. 6 Cross section.

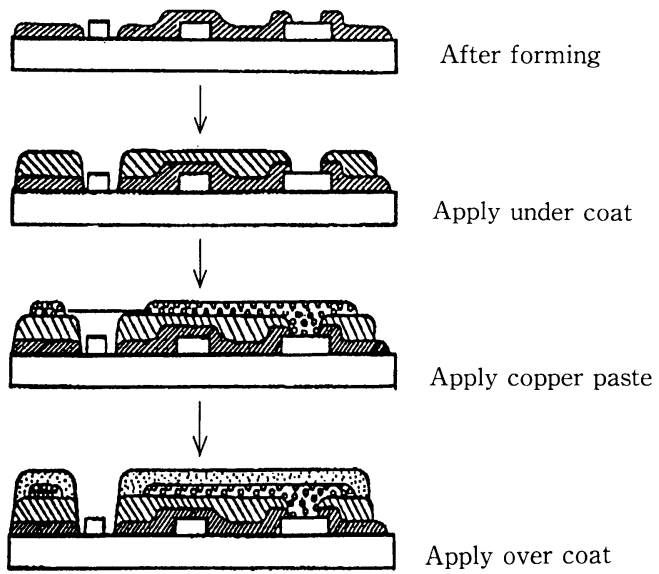

Fig.7 EMI shield PWB process.
基板から発生するノイズを低減する。

\section{(2) EMI 基板製造プロセス}

通常の基板と同様の方法で表面レジストまで作り，そ の上に絶縁材としてアンダーコートを形成し，その上に シールド層となる銅ペーストを形成して，さらにオーバ ーコート層シンボルインクを形成して，後工程に進む。

Fig.7にこのプロセスを示す。

アンダーコートから銅ペースト，オーバーコートはい ずれもスクリーン印刷法によって作るため, 部分的に選 択してシールドが可能であり，また基板の両面にシール ド層を設けることも可能である。

\section{(3) MUSE デコーダ基板でのノイズ削減効果}

EMI シールド基板を使ったときに，48.6 MHz クロ ックが Tab.3 に示すように減衰する。未対策基板に比 較して，GNDを $\mathrm{TH}$ を増して強化した基板はー $4 \mathrm{~dB}$ の削減，この上に銅ぺーストを形成した EMI シールド 基板では $-6 \mathrm{~dB}$ 減衰する。

(4) $18.4 \mathrm{MHz}$ (VCXO) 基板のノイズ削減

Tab.3 Noise level. (48.6MHz)

\begin{tabular}{c|c|c}
\hline Condition & Noise level & Effect \\
\hline Prototype version & $46 \mathrm{~dB}$ & - \\
\hline Added GND pattern & $42 \mathrm{~dB}$ & $4 \mathrm{~dB}$ \\
\hline EMI Shield board & $40 \mathrm{~dB}$ & $6 \mathrm{~dB}$ \\
\hline
\end{tabular}
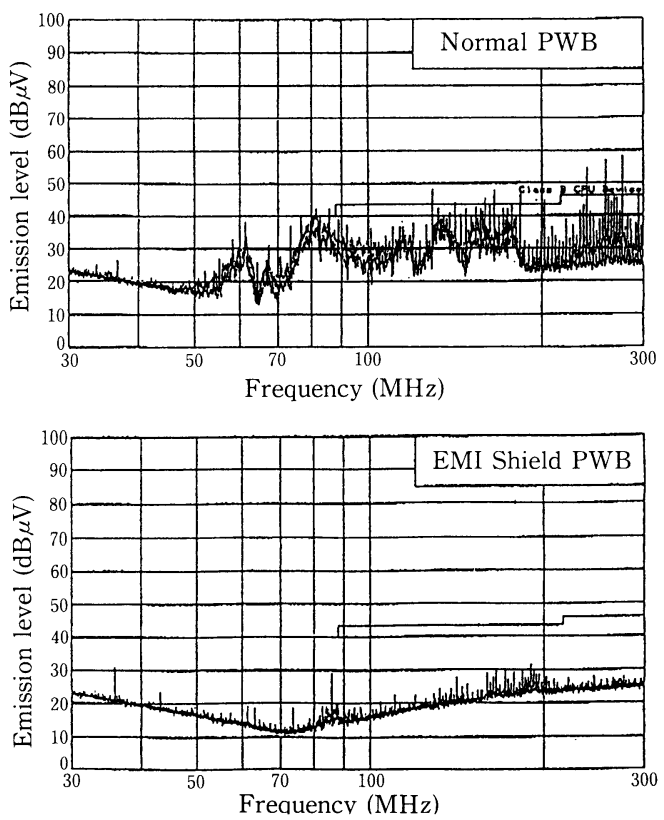

Fig. 8 Noise reduction of EMI shield board.

Vol.9, No.3 
クロック周波数 $18.4 \mathrm{MHz}$ ，信号レベル $6 \mathrm{~V}$ の基板に， EMI シールド基板を使った効果をFig.8に示す。 50 $\mathrm{MHz}$ 以上でー $20 \mathrm{~dB}$ 以上効果がある。

\section{5. 基 板 構 成}

ハイビジョンテレビは，4 層基板，両面基板，片面基 板の合計 20 種類で構成されている。Tab.4 に構成を示 す。デジタル処理用 LSI が多数搭載され, 多くの配線 が必要となる MUSE デコーダ用基板には 4 層基板を, フィーチャー回路には, 両面実装でリフローが対応でき る両面基板を, 高圧電源回路には, 耐トラッキング特性 を満足する片面基板を採用している。

\section{(1) MUSE デコーダ用基板の設計}

4 層基板を採用したデジタル回路と周辺のアナログ回 路を含むMUSEデコーダ用基板は, ケーデンス社の ALLEGRO を使用し，設計した。

ネットリスト (ピンからピンへの接続データリスト) を介しての設計は, 途中変更の際にメリットがあり, 今 回のモデルの日程短縮に大変効果があった。回路図から

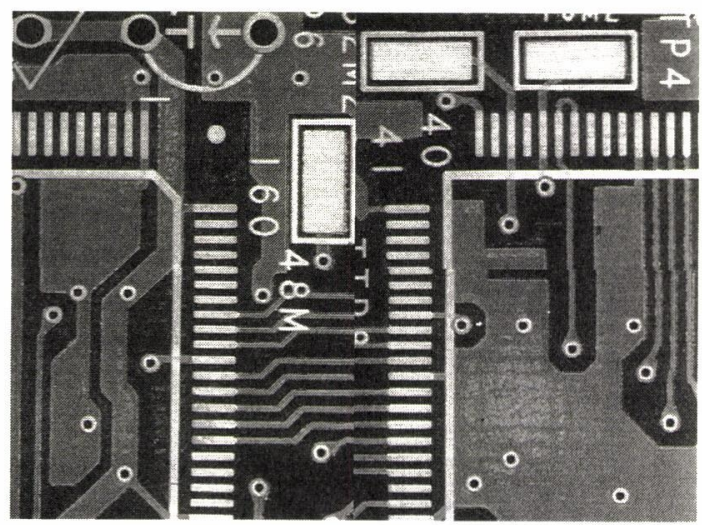

Fig. 9 Connect to each LSI by shortest.
ネットリストを作成し，これを CAD に入力する。CAD 上では，ネットリストにより部品間の接続情報が画面に 表示され，パターンを結線していく。途中変更はこのネ ットリストを変更するだけで，ラッツネスト（画面上に ネットリストを基に配線する 2 点間を表示する）が使え る。画面上に変更になった配線経路が表示され，これに 従い，簡単に確実に結線できる。MUSEデコーダ用 IC は，信号線の配線を最短距離で結線できる位置に配置す る (Fig.9)。

その後，CADによる自動配線やノイズシミュレーシ ヨンを使い, 基板の設計日程を短縮し, さらにパ夕ーン 配線 1 本毎にDRC（基板設計ルールに従ったチェック） ができるため, 基板設計後のチェックも非常に楽になっ た。このようにして, 配線のミスを著しく減少させ, 品 質の良い基板ができた。

\section{(2) 4 層基板}

基板の内層には, 電源・GND 回路の配線を行い, 外 層には信号回路の配線を行った。配線ルールとして最小 パターン幅・間隙ともに $0.15 \mathrm{~mm}$ としている。これは, 他の両面基板や片面基板と同様の製造ハンドリングがで きるように，銅箔ピール強度やエッチング精度を考慮し たためである。また，電気接続用 VIA ホールは, $\phi 0.4 \mathrm{~mm}$ の小径を採用して密度を上げた。外層におけ る GND 回路には多数の VIA ホールを配置し，導通抵 抗値を低減させている。

部品の実装は, チップ部品とディスクリート部品の混 載であり，基板には，自動装着機用のガイド穴を設け， 穴位置精度を確保するため 1 次加工穴仕様とした。パ夕 ーンとソルダーレジストは，印刷法より位置精度再現性 の良い写真法（液状レジスト）を使用し, 生産性を向上 させた。外形は，量産対応用のため金型による加工とし， 基板表面は耐熱プリフラックス処理し，はんだ付け品質 を保証した。基板板厚は，部品リードのクリンチ（リー ド線曲げ）量を両面基板や片面基板と同様にするため,

Tab.4 Composition OB PCBS

\begin{tabular}{c|c|c|c}
\hline & 4 Layer board & Double sided board & Single sided board \\
\hline Mount condition & Double sided mount & Double sided mount & Single sided mount \\
\hline Parts & Chip parts \& discrete parts & Chip parts \& discrete parts & Discrete parts \\
\hline Soldering & Reflow +Flow & Reflow + Flow & Flow \\
\hline Base material & FR-4 & CEM- 3 & FR- 1 \\
\hline Design rule & $0.15 \mathrm{~mm}$ & $0.25 \mathrm{~mm}$ & $0.25 \mathrm{~mm}$ \\
\hline Aspect ratio & 4 & 3 & - \\
\hline Boards & 3 & 10 & 7 \\
\hline
\end{tabular}




\section{$1.6 \mathrm{~mm}$ とした。}

\section{(3)両面基板}

MUSE デコーダ用基板以外のフィーチャー基板は, 両面基板を使用した。基板設計ルールは，最小パターン 幅・間隙ともに $0.25 \mathrm{~mm}$ としており，基板製造上の歩留 りを向上させている。しかも, 基板アスペクト比は 3 以 下としたため, 基板品質は良好で安心して使用できた。 基板サイズは，キララバッソと同じ $245 \times 162$ サイズを 採用し, 同じ量産ラインで生産できるものとした。外形 は金型による加工としている。基板表面は，これも耐熱 プリフラックス処理をした。

\section{(4)片面基板}

電源・偏向回路用基板には, 高圧回路に適した耐卜ラ ッキング特性（ソニー法によるパターン間のトラッキン グ電圧： $200 \mathrm{~V}$ 以上）を有する, 紙フェノール基材の片 面基板を採用している。部品の実装はディスクリート部 品のみの片面実装であり, 基板設計ルールは, 最小パ夕 ーン幅・間隙ともに $0.25 \mathrm{~mm}$ を採用している。また，市 場での品質を確保するため, はんだフィレットを高くす
る，ランド形状やハトメを採用している。基板サイズは $245 \times 328$ を基本とし, 幅方向を $245 \mathrm{~mm}$ に統一してい る。基板表面は一般的なプリフラックス処理をした。

\section{6. 今後の課題}

ハイビジョンテレビは, 各社から続々と発売されてき ており，いよいよ各家庭への普及に向かってさらなるコ ストダウンが必要となる。

実装面では，LSI 化の進むIC システムを，高精細な 基板に高密度に実装する技術が求められる。これを品質 良く実装できる新基板の開発実用化と多層基板設計 $\mathrm{CAD}$ の進歩, また小型・高密度化に伴い, より一層ノイ ズの影響が大きくなるため，ノイズ削減技術が重要にな る。さらに, デジタル化, 多機能化による消費電力のア ップをいかに削減するか。信頼性向上のために重要な機 内温度の低下のために放熱設計も重要になろう。しかも， これらのシミュレーションにも設計の早い段階から取り 組む必要がある。
山田英幸 (やまだ Uでゆき)

〔執筆者紹介〕

ソニ一(侏映像機器開発本部 ハイビジョン開発部

小松信夫(こまつ のぶお)

ソニ一侏電子デバイス事業本部 エレクトロケミカル事業部
榧場正男 (かやば まさお)

ソニー(侏映像関連技術部門 コンポーネント技術部

森田紘二(もりたこうじ)

ソニー(陎映像関連技術部門 コンポーネント技術部 